\title{
PENINGKATAN HASIL BELAJAR MATEMATIKA SISWA DENGAN MODEL PEMBELAJARAN KOOPERATIF TIPE TWO STAY-TWO STRAY
}

\author{
${ }^{1}$ Ida Istiqomah, ${ }^{2}$ Della Maulidiya, ${ }^{3}$ Teddy Alfra Siagian \\ 1,2,3 Prodi Pendidikan Matematika FKIP Universitas Bengkulu \\ email : ${ }^{1}$ idaistiqomah0@gmail.com, ${ }^{2}$ della.maulidiya@unib.ac.id, ${ }^{3}$ teddysiagian@unib.ac.id
}

\begin{abstract}
Abstrak
Penelitian ini bertujuan untuk mengetahui bagaimana cara meningkatkan hasil belajar matematika siswa dengan penerapan pembelajaran kooperatif tipe Two Stay Two Stray (TS-TS). Penelitian ini merupakan penelitian tindakan kelas (Classroom Action Research) dengan teknik pengumpulan data melalui tes hasil belajar. Subjek dalam penelitian ini adalah siswa kelas VII A SMP Negeri 13 Kota Bengkulu Tahun Ajaran 2017/2018 yang terdiri dari 30 siswa. Penelitian ini menunjukkan bahwa melalui penerapan pembelajaran kooperatif Tipe Two Stay Two Stray (TS-TS) pada pembelajaran matematika pokok bahasan segiempat dan segitiga dapat meningkatkan hasil belajar siswa. peningkatan hasil belajar siswa dapat dilihat dari nilai rata rata tes hasil belajar siswa pada siklus I mencapa 58,42; pada siklus II mencapai 76,97; dan pada siklus III mencapai 80.93. Ketuntasan Klasikal pada siklus I hanya mencapai 16,67\%; pada siklus II mencapai 63,33\%; dan siklus III mencapai 83,33\%.
\end{abstract}

Kata Kunci: Pembelajaran Kooperatif, Two Stay Two Stray (TS - TS), Hasil Belajar Siswa

\begin{abstract}
The purpose of this research is to know how to improve student learning achievement by Using Cooperative Learning Two Way Two Stray (TS TS). This research is a Classroom Action Research (CAR), where the data collection technique used test of learning achievement. The subjects of this research are the students of class VII/A at SMPN 13 Kota Bengkulu in academic year 2017/2018 which consists of 30 students. The results of this study indicate that the use of Cooperative Learning Two Way Two Stray Learning (TS TS) in mathematics learning with rectangular and triangular subjects can improve students' learning outcomes on mathematics. This is supported by the improvement of the average score of the students' mathematics learning, which in cycle I reach 58.42, thecycle II reaches 76.97, and the cycle III reaches 80.93. Meanwhile, the results of Classical Completeness also showed an improvement, which in cycle I reached $16.67 \%$, cycle II reached $63.33 \%$, and cycle III reached $83.33 \%$.
\end{abstract}

Keyword : cooperative learning, two stay two stray (TS - TS), students achievement.

\section{PENDAHULUAN}

Pembelajaran matematika merupakan salah satu mata pelajaran yang disampaikan di semua jenjang pendidikan. Namun pada umumnya mata pelajaran matematika masih menjadi momok tersendiri bagi siswa. Hal ini dapat dilihat dari hasil wawancara yang telah peneliti lakukan oleh peneliti terhadap guru matematika yang mengajar di kelas VII A SMP Negeri 13 Kota Bengkulu, yaitu ibu Rukayawati, S.Pd bahwa nilai matematika yang diperoleh siswa saat ujian akhir semester ganjil masih rendah. Rata -

IdaIstiqomah, Della Maulidiya, Teddy Alfra Siagian 
rata hasil ujian akhir semester ganjil kelas VII A SMP Negeri 13 Kota Bengkulu 35,9. Dari 30 siswa belum ada siswa yang mencapai mendapatkan nilai mencapai KKM. KKM yang telah ditentukan sekolah yaitu 72,00. Pembelajaran matematika yang dilakukan di kelas VII A SMP Negeri 13 Kota Bengkulu terlihat masih belum optimal dan perlu ditingkatkan lagi.

Zainuddin, Budiyono, dan Sujadi (2014 : 122) two stay two stray (TS-TS) yaitu salah satu tipe pembelajaran kooperatif yang memberikan kesempatan kepada kelompok membagikan hasil dan informasi kepada kelompok lain. Dengan model pembelajaran ini diharapkan siswa terlibat aktif, baik secara individual maupun dalam kelompok belajar. Selain itu model pembelajaran kooperatif tipe two stay two stray (TS-TS) siswa tidak hanya belajar dan menerima materi yang diberikan oleh guru, melainkan bisa belajar dari siswa lainnya dan sekaligus mempunyai kesempatan untuk membagikan hasil informasi dengan kelompok lain melalui metode diskusi.Salah satu kelebihan model pembelajaran kooperatif tipe two stay two stray (TS-TS) dapat diterapkan di semua kelas/tingkatan. Sehingga model pembelajaran kooperatif tipe two stay two stray (TS-TS) ini dapat diterapka di kelas VII A SMP Negeri 13 Kota Bengkulu. Diharapkan melalui model pembelajaran kooperatif tipe two stay two stray, siswa dapat belajar dengan lebih nyaman dan senang. Selain itu model pembelajaran kooperatif tipe two stay two stray (TS-TS) siswa diharapkan dapat belajar dalam kelompok dan saling berdiskusi dengan sesame teman.

Rumusan masalah dalam penelitian ini adalah bagaimana cara menerapkan model pembelajaran kooperatif tipe Two Stay Two stray (TS-TS) untuk meningkatkan hasil belajar matematika siswa kelas VII A SMP Negeri 13 Kota Bengkulu

Belajar adalah pencapaian bentuk perubahan tingkah laku yang cenderung menetap dari ranah kognitif, afektif dan psikomotorik dari proses belajar yang dilakukan dalam waktu tertentu (Haris dan Jihad, 2013 : 14). Haris dan Jihad (2013 : 14) mendefinisikan hasil belajar adalah pencapaian bentuk perubahan tingkah laku yang cenderung menetap dari ranah kognitif, afektif, dan psikomotorik dari proses belajar yang dilakukan dalam waktu tertentu.

Sudjana berpendapat, hasil belajar adalah kemampuan - kemampuan yang dimiliki siswa setelah ia menerima pengalaman belajarnya. Menurut Fitri, Helma, dan Syarifuddin (2014 : 19) hasil belajar adalah penguasaan yang dicapai oleh siswa setelah mengikuti proses pembelajaran. Beberapa pendapat tersebut, dapat dikatakan bahwa hasil belajar adalah perubahan tingkah laku dalam ranah kognitif, afektif, dan psikomotor yang terjadi setelah mengikuti proses belajar mengajar. Hasil belajar mempunyai peranan penting dalam proses pembelajaran. proses penialaian terhadap hasil belajar dapat memberikan informasi kepada guru tentang kemajuan siswa dalam upaya pencapaian tujuan pembelajaran.

Spancer Kagan berpendapat bahwaTwo Stay Two Stray (TS-TS) merupakan salah satu pembelajaran kooperatif yang memberikan kesempatan kepada kelompok untuk berbagi pengetahuan dan pengalaman dengan kelompok lain, dimana ada dua anggota kelompok yang tinggal dan ada dua anggota kelompok yang bertamu (Lestari dan Yudhanegara, $2015: 51$ ). 
Tabel 1 Tahapan Two Stay Two STray

\begin{tabular}{|c|c|}
\hline Fase & Deskripsi \\
\hline Tahap 1 & $\begin{array}{l}\text { Guru membagi siswa dalam } \\
\text { beberapa kelompok yang setiap } \\
\text { kelompoknya terdiri dari empat } \\
\text { siswa. Kelompok yang dibentuk } \\
\text { merupakan kelompok heterogen. }\end{array}$ \\
\hline Tahap 2 & $\begin{array}{l}\text { Guru memberikan subpokok } \\
\text { bahasan pada tiap }- \text { tiap } \\
\text { kelompok untuk dibahas } \\
\text { bersama dengan anggota } \\
\text { kelompok masing - masing. }\end{array}$ \\
\hline Tahap 3 & $\begin{array}{l}\text { Siswa bekerja sama dalam } \\
\text { kelompok yang beranggotakan } \\
\text { empat orang. }\end{array}$ \\
\hline Tahap 4 & $\begin{array}{l}\text { Dua orang dari masing - masing } \\
\text { kelompok meninggalkan } \\
\text { kelompoknya untuk bertamu ke } \\
\text { kelompok lain. }\end{array}$ \\
\hline Tahap 5 & $\begin{array}{l}\text { Dua orang yang tinggal dalam } \\
\text { kelompok berfungsi } \\
\text { membagikan hasil kerja dan } \\
\text { informasi mereka kepada tamu } \\
\text { dari kelompok lain. }\end{array}$ \\
\hline Tahap 6 & $\begin{array}{l}\text { Tamu mohon diri dan kembali } \\
\text { ke kelompok mereka sendiri } \\
\text { untuk melaporkan temuan } \\
\text { mereka dari kelompok lain. }\end{array}$ \\
\hline Tahap 7 & $\begin{array}{l}\text { Kelompok mencocokkan dan } \\
\text { membahas hasil kerja mereka. }\end{array}$ \\
\hline Tahap 8 & $\begin{array}{l}\text { Masing - masing kelompok } \\
\text { mempresentasikan hasil kerja } \\
\text { mereka. }\end{array}$ \\
\hline
\end{tabular}

Pada penelitian ini peneliti menggunakan pendekatan saintifik. Karena salah satu kekurangan model two stay two stray adalah siswa yang kurang pandai akan bergantung pada siswa yang pandai. Untuk mengatasi kekurangan tersebut maka perlu ada upaya untuk membantu siswa menemukan konsep. Sehingga jika siswa sudah menemukan konsepnya, siswa akan mudah untuk melakukan komunikasi saat siswa yang stay menjawab pertanyaan dan siswa yang stray bertanya. Pendekatan saintifik ini membantu siswa untuk menemukan konsep di tahap diskusi kelompok pada model Two Stay Two Stray.

Model pembelajaran kooperatif merupakan salah satu model yang sesuai dengan prinsip - prinsip pendekatan saintifik. Untuk itu peneliti membuat langkah - langkah pembelajaran kooperatif tipe two stay two stray (TS - TS) dengan menggunakan langkah - langkah saintifik yang diuraikan dalam tabel 2 berikut :

Tabel 2 Langkah - langkah pembelajaran matematika menggunakan model pembelajaran two stay two stray (TS - TS) dengan pendekatan saintifik

\begin{tabular}{|c|l|}
\hline Fase & \multicolumn{1}{|c|}{ Deskripsi } \\
\hline Tahap 1 & $\begin{array}{l}\text { Guru membagi siswa dalam } \\
\text { beberapa kelompok yang } \\
\text { setiap kelompoknya terdiri } \\
\text { dari empat siswa. Kelompok } \\
\text { yang dibentuk merupakan } \\
\text { kelompok heterogen. }\end{array}$ \\
\hline Tahap 2 & $\begin{array}{l}\text { Guru memberikan subpokok } \\
\text { bahasan pada tiap - tiap } \\
\text { kelompok untuk dibahas } \\
\text { bersama dengan anggota } \\
\text { kelompok masing - masing. }\end{array}$ \\
\hline Tahap 3 & $\begin{array}{l}\text { Siswa bekerja sama dalam } \\
\text { kelompok yang beranggotakan } \\
\text { empat orang. (mengamati, } \\
\text { menanya, mengumpulkan } \\
\text { informasi, menalar) }\end{array}$ \\
\hline Tahap 4 & $\begin{array}{l}\text { Dua orang dari masing - } \\
\text { masing kelompok } \\
\text { meninggalkan kelompoknya } \\
\text { untuk bertamu ke kelompok } \\
\text { lain. (menanya) }\end{array}$ \\
\hline Tahap 5 \\
kelompok yang tinggal dalam \\
\hline
\end{tabular}




\begin{tabular}{|c|l|}
\hline Fase & \multicolumn{1}{|c|}{ Deskripsi } \\
\hline & $\begin{array}{l}\text { membagikan hasil kerja dan } \\
\text { informasi mereka kepada tamu } \\
\text { dari lain. } \\
\text { (mengkomunikasikan) }\end{array}$ \\
\hline Tahap 6 & $\begin{array}{l}\text { Tamu mohon diri dan kembali } \\
\text { ke kelompok mereka sendiri } \\
\text { untuk melaporkan temuan } \\
\text { mereka dari kelompok lain. }\end{array}$ \\
\hline Tahap 7 & $\begin{array}{l}\text { Kelompok mencocokkan dan } \\
\text { membahas hasil kerja mereka. } \\
\text { (menalar, mengomunikasikan) }\end{array}$ \\
\hline Tahap 8 & $\begin{array}{l}\text { Masing - masing kelompok } \\
\text { mempresentasikan hasil kerja } \\
\text { mereka.(mengkomunikasikan) }\end{array}$ \\
\hline
\end{tabular}

Penelitian ini menggunakan LKPD untuk diselesaikan oleh siswa pada tahap diskusi kelompok Pengertian lembar kerja siswa (LKS) sebagaimana diungkap dalam pedoman umum pengembangan bahan ajar (Diknas, 2004), yaitu lembar kegiatan siswa (student worksheet) adalah lembaran lembaran berisi tugas yang harus dikerjakan oleh siswa. Lembar kerja biasanya berupa petunjuk atau langkah - langkah untuk menyelesaikan suatu tugas.

Trianto (2010:222-223) mengemukakan bahwa LKS merupakan panduan siswa yang digunakan untuk melakukan kegiatan penyelidikan atau pemecahan masalah. LKS memuat sekumpulan kegiatan mendasar yang harus dilakukan oleh siswa untuk memaksimalkan pemahaman dalam upaya pembentukan kemampuan dasar sesuai indikator pemcapaian hasil belajar yang harus ditempuh.

Penjelasan tersebut dapat kita ketahui bahwa LKS merupakan suatu bahan ajar berupa lembaran- lembaran kertas yang berisi materi, ringkasan, dan petunjuk pelaksanaan tugas pembelajaran yang harus dikerjakan siswa yang mengacu pada kompetensi dasar yang harus dicapai. LKS menurut Prastowo (2015 : 205-206) sebagai bahan ajar memiliki 4 (empat) fungsi, sebagai berikut :

1. Sebagai bahan ajar yang bisa meminimalkan peran pendidik, namun lebih mengaktifkan siswa.

2. Sebagai bahan ajar yang mempermudah siswa untuk memahami materi yang diberikan.

3. Sebagai bahan ajar yang ringkas dan kaya tugas untuk berlatih

4. Memudahkan pelaksanaan pengajaran kepada siswa.

Tujuan penyusunan LKS menurut Prastowo (2015 : 206) ada 4 (empat), sebagai berikut :

1. Menyajikan bahan ajar yang mempermudah siswa untuk berinteraksi dengan materi yang diberikan

2. Menyajikan tugas - tugas yang meningkatkan penguasaan siswa terhadap materi yang diberikan.

3. Melatih kemandirian belajar siswa.

4. Memudahkan pendidik dalam memberikan tugas kepada siswa.

Hasil belajar siswa yang akan dilihat pada penelitian ini adalah pada ranah kognitif. Hasil belajar dilakukan pada pertemuan ke empat dalam waktu 1 x 40 menit berupa tes hasil belajar.

\section{METODE PENELITIAN}

Jenis penelitian yang digunakan adalah Penelitian Tindakan Kelas (PTK). Penelitian ini dilaksanakan dalam 3 siklus. Ada empat tahap dalam pelaksanaan, yaitu : 1) perencanaan tindakan, 2) pelaksanaan Tindakan, 3) pengamatan terhadap tndakan dan 4) refleksi terhadap tindakan. Penelitian ini dilaksanakan 


\section{SUBJEK PENELITIAN}

Subjek penelitian ini adalah seluruh siswa kelas VII Adi SMP Negeri 13 Kota Bengkulu Tahun Pelajaran 2017/2018 yang berjumlah 30siswa, dengan jumlah siswa laki-laki sebanyak 14 siswa dan jumlah siswa perempuan adalah 16 .

\section{TEMPAT DAN WAKTU PENELITIAN}

Penelitian ini dilaksanakan di SMP Negeri 13 Kota Bengkulu yang beralamat di jalan Soekarno-Hatta, Kelurahan Anggut Atas, Kecamatan Ratu Samban, Kota Bengkulu, Provinsi Bengkulu pada semester genap tahun pelajaran 2017/2018 yaitu bulan Maret 2018 sampai Mei 2018.

\section{PROSEDUR PENELITIAN}

Ada empat tahapan pelaksanaan PTK, yaitu : perencanaan tindakan (planning), pelaksanaan tindakan (acting), pengamatan terhadap tindakan (observing) dan refleksi terhadap tindakan (reflecting).

\section{INSTRUMEN PENELITIAN}

Instrument penelitian ini adalah lembar tes hasil belajar. Tes merupakan alat atau prosedur yang digunakan untuk mengetahui atau mengukur sesuatu dalam suasana, dengan cara dan aturan - aturan yang sudah ditentukan. (Arikunto, 2009 : 53). Lembar tes yang digunakan dalam hal ini yaitu lembar tes hasil belajar siklus I, siklus II, dan siklus III. Tes dibuat mengacu pada kompetensi dasar dan indikator yang telah dibuat, berupa tes tertulis.

\section{TEKNIK PENGUMPULAN DATA}

Pengumpulan data dilakukan dengan cara tes di tiap akhir siklus. Tes digunakan untuk mengukur tingkat pemahaman atau hasil siswa terhadap materi pelajaran yang akan diajarkan. Tes dilakukan pada setiap akhir siklus selama 40 menit (1 x JP).

\section{TEKNIK ANALISIS DATA}

Untuk menganalisis data yang diperoleh, peneliti menggunakan hasil rata - rata dan ketuntasan belajar klasikal siswa. Tes hasil belajar dengan menggunakan rumus nilai rata-rata, yaitu:

$$
\begin{aligned}
& \bar{x}=\frac{\sum X}{N} \\
& \text { Sumber : Aqib (2014:40) }
\end{aligned}
$$

Keterangan:

$\bar{x}=$ Mean (nilai rata-rata kelas)

$\sum X=$ Jumlah seluruh nilai peserta didik

$\mathrm{N}=$ Banyak peserta didik

Presentase ketuntasan belajar klasikal dengan rumus, yaitu:

$$
\mathrm{P}=\frac{\sum \text { Siswa yang tuntas belajar }}{\sum_{\times 100 \%} \text { siswa }}
$$

Keterangan:

Sumber: Aqib (2014:41)

$$
\begin{aligned}
& \mathrm{P}=\text { Ketuntasan } \\
& \sum=\text { Jumlah }
\end{aligned}
$$

Peserta didik dikatakan tuntas belajar jika memperoleh nilai $\geq 72$.

\section{HASIL DAN PEMBAHASAN}

Tujuan penelitian ini untuk meningkatkan hasil belajar siswa dengan melakukan penerapan model pembelajaran kooperatif tipe two stay two stray (TS-TS). Pelaksanaan siklus I diperoleh bahwa siswa belum terbiasa dengan model pembelajaran kooperatif tipe two stay two stray (TS-TS) dengan menggunakan LKPD. Hal ini dapat dilihat dari pengerjaan LKPD yang diberikan oleh guru pada setiap kelompok. Tahap mengamati siswa siswa kesulitan dalam menjawab pertanyaan yang diberikan 
seputar materi yang telah dipelajari sebelumnya. Guru mengatasi hal tersebut dengan mengingatkan siswa mengenai materi prasyarat tersebut.

Tahap menanya siswa masih bingung dalam membuat pertanyaan. Hal ini diatasi oleh guru dengan membimbing setiap kelompok dalam membuat pertanyaan dan membaca petunjuk yang ada pada LKPD. Tahap menggali informasi kesalahan siswa terjadi karena siswa belum teliti melakukan pengukuran. Untuk mengatasi hal tersebut guru selalu mnegingatkan siswa untuk teliti dalam mengukur. Guru juga membimbing siswa yang masih bingung dalam menggunkana penggaris maupun busur derajat. tahap menalar siswa kesulitan dalam membuat kesimpulan dari tahapan - tahapan yang telah mereka lakukan sebelumnya. Untuk mengatasi hal tersebut guru mengingatkan siswa untuk teliti dalam mengerjakan LKPD dan menyelesaikan setiap tahapan - tahapan pada LKPD.

Tahap mengkomunikasikan guru membimbing siswa untuk melakukan tahap two stay two stray (TS-TS) sesuai petunjuk yang ada pada LKPD. Setelah siswa selesai pada tahap siswa diarahkan untuk bertanya bagi siswa yang bertamu dan menjelaskan bagi siswa yang tinggal.

Setelah siswa selesai berdiskusi dalam waktu yang ditentukan oleh guru, siswa yang bertamu kembali ke kelompoknya masing -masing. Selanjutnya siswa akan diarahkan untuk berdiskusi kembali bersama kelompoknya mengenai informasi yang diperoleh siswa yang bertamu. Setelah selesai berdiskusi perwakilan kelompok akan mempresentasikan LKPD yang telah mereka diskusikan, sedangkan kelompomyang tidak presentasi akan menanggapinya.
Setelah 4 kali pertemuan guru memberikan tes hasil belajar di akhir pelajaran selama 1 x 40 menit. pada soal tes tersebut guru memberikan soal berupa persamaan linier satu variabel. Hal ini menjadi salah satu penyebab nilai hasil belajar siswa belum mencapai kriteria keberhasilan yang telah ditetapkan.

Siklus II siswa sudah mulai terbiasa dengan pembelajaran menggunakan model two stay two stray (TS-TS). Hal ini dapat dilihat dari pengerjaan LKPD siswa. Tahap mengamati siswa mengikuti arahan guru untuk bersama - sama mengamati gambar yang disediakan di LKPD di tempat duduk masing - masing. Tahap menanya semua kelompok sudah mengikuti arahan guru dalam membuat pertanyaan sesuai petunjuk yang ada pada LKPD. Namun masih ada kelompok yang belum mengerjakan dengan tepat. Hal ini diatasi guru dengan cara membimbing kelompok yang masih bingung dalam membuat pertanyaan pada tahap menanya.

Tahap menggali informasi siswa di arahkan untuk mengukur gambar permukaan benda - benda menggunakan penggaris, busur derajat, maupun jangka. Dalam hal ini siswa masih belum teliti dalam pengukuran. Namun siswa tampak antusias dalam menggunakan jangka. Tahap menalar siswa diarahkan untuk menarik kesimpulan dari tahap - tahap yang telah mereka kerjakan sebelumnya. Guru mengarahkan siswa untuk melihat kembali data - data yang mereka peroleh pada tahap sebelumnya untuk memperoleh kesimpilan sesuai pertanyaan yang ada pada LKPD.

Tahap mengkomunikasikan siswa diarahkan untuk tetap tertib pada saat proses perpindahan kelompok. Guru selalu 
mengingatkan siswa untuk mengerjakan LKPD secara bersama - sama sehingga semua kelompok dapat memahami proses menemukan konsep yang diinginkan agar pada saat proses perpindahan kelompok mereka dapat menjawab pertanyaan dari siswa yang bertamu.

Siklus III dilakukan dengan perbaikan perbaikan permasalahan pada siklus II. Pada siklus III ini siswa sudah terbiasa belajar menggunakan model two stay two stray (TSTS) menggunakan LKPD. Tahap menggali informasi siswa selalu di arahkan dan dibimbing untuk teliti dalam pengukuran maupun perhitungan. Berbeda dengan siklus II sebelumnya pada tahap menggali informasi siswa diarahkan untuk mengukur permukaan benda - benda. Sedangkan pada siklus III ini siswa di arahkan untuk teliti dalam perhitungan. Sehingga pada saat mengkomunikasikan dengan model two stay two stray (TS-TS) siswa tidak salah dalam memberik informasi kepada siswa yang bertamu. Peningkatan

Peningkatan hasil belajar siswa dapat dilihat pada tabel 3 berikut :

\section{Tabel 3 Hasil Belajar Siswa Tiap Siklus}

\begin{tabular}{|c|c|c|c|c|}
\hline Siklus & $\begin{array}{c}\text { Nilai } \\
\text { Rata- } \\
\text { rata }\end{array}$ & $\begin{array}{c}\text { Jumlah } \\
\text { Siswa } \\
\text { Tuntas } \\
\text { Belajar }\end{array}$ & $\begin{array}{c}\text { Ketuntasan } \\
\text { Belajar } \\
\text { Klasikal }\end{array}$ & Ket. \\
\hline I & 54,82 & 5 & $16,67 \%$ & $\begin{array}{c}\text { Belum } \\
\text { Tercapai }\end{array}$ \\
\hline II & 76,97 & 19 & $63,33 \%$ & $\begin{array}{c}\text { Belum } \\
\text { Tercapai }\end{array}$ \\
\hline III & 80,93 & 23 & $83,33 \%$ & Tercapai \\
\hline
\end{tabular}

Tabel 3 di atas menunjukkan bahwa terjadi peningkatan hasil belajar siswa secara berturut - turut dari siklus I hingga siklus III, yaitu nilai rata - rata siswa pada siklus I 58,42, siklus II 76,97 dan siklus III 80,93. Peningkatan hasil belajar siswa juga diikuti oleh ketuntasan hasil belajar siswa dari siklus I hingga siklus III. Persentase ketuntasan hasil belajar siswa siklus I sebesar $16,67 \%$, siklus II 63,33\% dan siklus III $83,33 \%$. Untuk mengatasi siswa yang belum mencapai nilai KKM yang telah ditentukan solusi guru adalah guru lebih fokus pada siswa - siswa yang nilainya belum mencapai KKM pada tes hasil belajar di akhir siklus. Guru terus membimbing dan mengarahkan siswa pada saat mengerjakan LKPD dalam proses menemukan konsep yang diharapkan.

Terdapat 16 siswa yang nilai tesnya meningkat terus dan terdapat 14 siswa yang nilainya naik turun. Gambar 4.76 menunjukkan bahwa pada siklus I nilai tertinggi yang diperoleh siswa yaitu 75, siklus II sebesar 94 dan siklus III sebesar 100. Sedangkan nilai terendah yang diperoleh siswa pada siklus I sebesar 27.5, siklus II sebesar 42 dan siklus III sebesar 59. Hal ini menunjukkan bahwa terjadi peningkatan hasil belajar siswa dari siklus I hingga siklus III.

Terdapat dua siswa yang nilainya belum mencapai KKM selama 3 siklus. Hal ini terjadi karena hasil pengematan oleh dua siswa tersebut sering keluar masuk dan belum aktif bertanya atau menanggapi pada saat diskusi kelompok. Dilihat dari tabel 4.9 dan gambar 4.76 hasil belajar siswa secara umum mengalami peningkatan. Hal ini menunjukkan bahwa hasil belajar siswa mengalami peningkatan di tiap siklus, yang artinya model pembelajaran kooperatif tipe Two stay two stray (TS-TS) dapat meningkatkan hasil belajar siswa di kelas VII A SMP Negeri 13 Kota Bengkulu.Peningkatan belajar klasikal siswa dapat dilihat pada grafik 1 berikut ini : 


\section{Ketuntasan Belajar} Klasikal

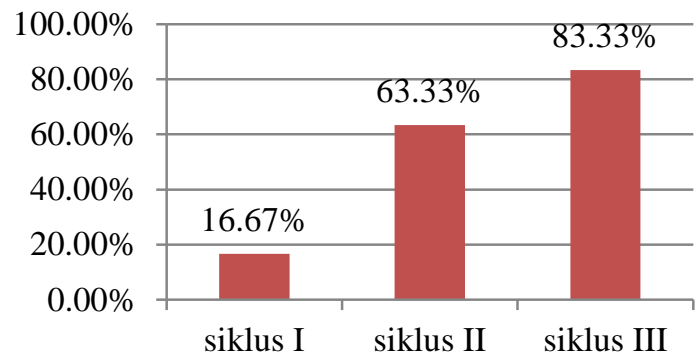

Gambar 1 Grafik Ketuntasan Belajar Klasikal Tiap Siklus

Gambar 1 di atas menunjukkan bahwa pada siklus I ketuntasan belajar klasikal siswa 16,67\%; pada siklus II $63,33 \%$ dan pada siklus III ketuntasan belajar klasikal siswa telah mencapai $83,33 \%$. Hal ini berarti ketuntasan belajar klasikal siswa mengalami peningkatan. Pada siklus III ketuntasan belajar klasikal yang diperoleh telah mencapai kriteria ketuntasan belajar klasikal yang telah ditentukan.

Berdasarkan hasil tes belajar siswa dari suklus I hingga siklus III dapat dilihat bahwa hasil tes belajar siswa mengalami peningkatan. Sehingga dapa disimpulkan bahwa penerapan model pembelajaran kooperatif tipe two stay two stray (TS-TS) dapat meningkatkan hasil belajar siswa kelas VII A SMP Negeri 13 Kota Bengkulu..

\section{PENUTUP}

\section{SIMPULAN}

Berdasarkan data dan analisis penelitian dengan menerapkan model pembelajaran kooperatif tipe two stay two stray (TS-TS), dapat meningkatkan hasil belajar siswa kelas VII A SMP Negeri 13 Kota Bengkulu dengan cara :

1. Tahap diskusi kelompok siswa di arahkan untuk mengamati, menanya, menggali informasi dan menalar sesuai petunjuk pada LKPD.

2. Siswa diarahkan untuk teliti dalam pengukuran pada saat diskusi kelompok mengerjakan LKPD.

3. Membimbing siswa pada saat mengerjakan LKPD sehingga siswa yang tinggal bisa menjelaskan pertanyaan dari siswa yang bertamu.

4. Guru fokus pada siswa yang nilainya belum mencapai KKM

\section{SARAN}

Berdasarkan penelitian yang telah dilaksanakan, terdapat saran sebagai berikut:

1. Kegiatan pembelajaran menggunakan model two stay stwo stray ini sebaiknya dilaksanakan dalam kelompok kecil, yaitu 4-5 siswa.

2. Guru mengarahkan siswa yang stray untuk bertanya mengenai materi yang belum dipahami. Sedangkan siswa yang stay guru mengarahkan untuk memahami materi pada saat diskusi kelompok agar mereka dapat menjelaskan kepada siswa yang stray.

\section{DAFTAR PUSTAKA}

Aini, Asro. 2016. Penerapan Model Pembelajaran Kooperatif Tipe Think Pair Share Dengan Pendekatan Saintifik Untuk Meningkatkan Aktivitas Dan Hasil Belajar Matematika Siswa Di Smp Negeri 11 Kota Bengkulu. Skripsi : UNIB.

Arikunto, S. 2009. Dasar - Dasar Evaluasi Pendidikan. Yogyakarta : Bumi Aksara.

Arzak dan Ibrahim, M. 2015. "Efektivitas Pembelajaran Kooperatif Tipe Two Stay Two Stray (TS-TS) terhadap Hasil Belajar Matematika Siswa Kelas VIII SMP Negeri 10 Kendari pada Pokok Bahasan Operasi Bentuk Aljabar". Skripsi. Kendari : Program S1 
Pendidikan Matematika, Universitas Halu Oleo.

Aqib, Zainal. 2016. Penelitian Tindakan Kelas untuk: Guru. Bandung: Yrama Widya.

Darmadi, H. 2014. Metode Penelitian Pendidikan dan Sosial. Bandung : Alfabeta.

Daryanto, dan Karim, S.yaiful. 2017. Pembelajaran Abad 21.Yogyakarta : Gava Media.

Daryanto. 2014.Pendekatan Pembelajaran Saintifik Kurikulum 2013. Yogyakarta : Gava Media.

Dimyati, dan Mudjiono. 2013. Belajar dan Pembelajaran. Jakarta : PT Rineka Cipta

Djamarah, S.B. dan Zain, A. 2006. Strategi Belajara Mengajar. Jakarta : PT Rineka Cipta.

Fajarantau, Anthur. 2016. Penerapan Pembelajaran Kooperatif Tipe Two Stay Two Stray (TS-TS) Untuk Meningkatkan Hasil Belajar M

Fitri, H, Helma dan Syarifuddin, Hendra. 2014. Penerapan Strategi The Firing Line pada Pembelajaran Matematika Siswa Kelas XI IPS SMA Negeri 1 Batipuh. UNP. Vol. 3 number 1, (2014). Diambil dari : http://ejournal.unp.ac.id/students/index .php/pmat/article/view/1214.

$(25$

Oktober 2017)

Haris, A. dan Jihad, A. 2013. Evaluasi Pembelajaran. Yogyakarta: Multi Pressindo.

Hernawan, Asep Herry. 2010. Pengembangan Kurikulum dan Pembelajaran. Jakarta: Universitas Terbuka.

Hidayat, N.A dan Maulana, M. 2017. "Efektivitas Model Pembelajaran Kooperatif Tipe Two Stay Two Stray (TS-TS) dan Model Pembelajaran Kooperatif Tipe Team Assisted
Individualization (TAI) terhadap Hasil Belajar Matematika. Skripsi. Semarang : Universitas Muhammadiyah Semarang.

Huda, Miftahul. 2017. Model Pengajaran dan Pembelajaran Isu-Isu Metodis dan Paradigmatis. Yogyakarta : Pustaka Pelajar

Kemendikbud. 2013. Materi Pelatihan Guru Implementasi Kurikulum 2013 SMP/MTs Matematika. Jakarta : Kmendikbud.

Kurniasih, Imas dan Berlin, Sani. 2014. Sukses Mengimplementasikan Kurikulum 2013. Jakarta : Kata Pena.

Lestari, E dan Yudhanegara, M.R. 2015. Penelitian Pendidikan Matematika. Karawang : Refika Aditama.

Prastowo, Andi. 2015. Panduan Kreatif Membuat Bahan Ajar Inovatif Menciptakan Metode Pembelajaran yang Menarik dan Menyenangkan. Jogjakarta : Diva Press.

Rusman. 2011. Model-Model Pembelajaran Mengembangkan Profesionalisme Guru. Jakarta: PT Raja Grafindo Persada.

Romiati, E., \& Theis, R. (2017). Pengembangan LKS Berbasis Pendekatan Saintifik dan Strategi Pembelajaran PQ4R pada Materi Himpunan Kelas VII SMPN 11 Kota Jambi. Edumatica, 38.

Saroinsong, J., Ali, M. M., \& Murdiana, I. N. (2016). Penerapan Pendekatan Saintifik untuk Meningkatkan Hasil Belajar Siswa pada Materi Grafik Fungsi Eksponen di Kelas X MIA 6 SMAN 4 Palu. Jurnal Elektronik Pendidikan Matematika Tadulako, 54.

Sani, R.A. 2014. Pembelajaran Saintifik untuk Implementasi Kurikulum 2013. Jakarta : Bumi Aksara. 
Sardiman, A.M. 2014. Interaksi dan Motivasi Belajar Mengajar. Jakarta : Rajawali.

Shoimin, A. 2014. 68 Model Inovatif dalam Kurikulum 2013. Yogyakarta: Ar-ruzz Media. (Saroinsong, Ali, \& Murdiana, 2016)

Sudijono, Anas. 2008. Pengantar Evaluasi Pendidikan. Jakarta: PT Raja Grafindo Persada.

Sudjana, Nana. 2016. Penilaian Hasil Proses Belajar Mengajar. Bandung: PT. Remaja Rosdakarya.

Trianto. 2010. Panduan Lengkap Penelitian Tindakan Kelas/Classroom Action Research]. Surabaya : Prestasi Pustakaraya. 